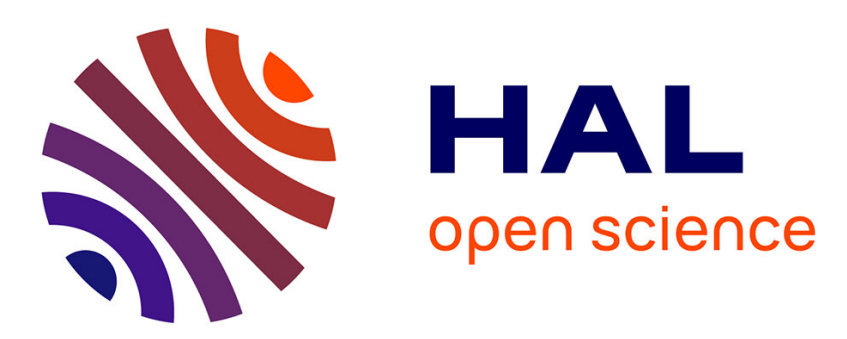

\title{
Suburban pastoral: Strawberry Fields forever and Sixties memory
}

Stephen Daniels

\section{To cite this version:}

Stephen Daniels. Suburban pastoral: Strawberry Fields forever and Sixties memory. cultural geographies, 2006, 13 (1), pp.28-54. 10.1191/1474474005eu349oa . hal-00572170

HAL Id: hal-00572170

https://hal.science/hal-00572170

Submitted on 1 Mar 2011

HAL is a multi-disciplinary open access archive for the deposit and dissemination of scientific research documents, whether they are published or not. The documents may come from teaching and research institutions in France or abroad, or from public or private research centers.
L'archive ouverte pluridisciplinaire HAL, est destinée au dépôt et à la diffusion de documents scientifiques de niveau recherche, publiés ou non, émanant des établissements d'enseignement et de recherche français ou étrangers, des laboratoires publics ou privés. 


\title{
Suburban pastoral: Strawberry Fields forever and Sixties memory
}

\author{
Stephen Daniels \\ School of Geography, University of Nottingham
}

\begin{abstract}
As a cultural period the $1960 \mathrm{~s}$ is produced through overlapping forms of social memory in which private and public recollections overlap. In both sound and imagery, pop music, particularly that of the Beatles, is a principal medium of memory for the period. For the period from 1965, the progressive aspects of pop music, particularly in sonic and lyrical complexity, expressed a retrospective, pastoral strain that was itself a form of memory of other periods and places, of childhood and country life. The Beatles double-A-sided single Strawberry Fields forever/Penny Lane, released in February 1967, epitomizes these complexities in a suburban version of pastoral, recalling the Liverpool childhoods of songwriters John Lennon and Paul McCartney. An analysis of the production and reception of the record, including lyrical genesis and musical development, publicity imagery, reviews in both the popular music papers and national news press, and the impact of the record in Liverpool and London, identifies the importance of intense, immediate moments in cultural geography, and their connection to longer developments in a theatre of memory that plays comedy and history as well as tragedy.
\end{abstract}

$I_{\text {o }}$ can remember the Sixties, which means I wasn't there. An impressionable 16- yearold in February 1967, I clearly recall the release of the Beatles' double-A-sided single Strawberry Fields forever/ Penny Lane, played repeatedly on the pirate station Radio London. If the record extended the group's adventurous recordings of the previous year, and echoed obscurities on the progressive play list of the lower sixth, as a pop single it sounded like nothing else. It looked different too. In an innovative picture sleeve and promotional film for television, the Beatles emerged from months of media exile with a new bohemian image: long coats, big hats, beards, moustaches and serious expressions. Penny Lane and Strawberry Fields, we heard, were real places, childhood haunts of Lennon and McCartney, but the strange sonic and lyrical landscape of the record haunted those who had never been to Liverpool and knew nothing of the Beatles' upbringing there.

Everyone can remember the Sixties. In the prevailing culture of memory, in which (as in the above paragraph) personal memories grounded in lived experience are conflated with collective memories retrieved from public media, the Sixties are layered by overlapping modes of recollection, including reminiscence, revival, conservation and 
commemoration, with pop music in general, and that of the Beatles in particular, shaping the period's reproduction and the places associated with it. ${ }^{1}$ The memory market for the Beatles in Liverpool is presently estimated at over $£ 20$ million annually in tourist revenue. The Penny Lane roundabout and gates of the Strawberry Field orphanage in south Liverpool have long been enshrined in itineraries; recently the National Trust has restored the childhood homes of John Lennon and Paul McCartney close by, with visits by special minibus from the city's top heritage attraction, Albert Dock, home to the exhibition and emporium The Beatles Story. ${ }^{2}$ There are different, sometimes competing, narratives in these layers of recollection, even in plot lines which give primacy to Liverpool. Some works offer a unified group perspective, notably the official Beatles anthology project (1995-2000), a series of documentary films, CD sets and eventually a book, which for one critic, attached to the group's early image as tough rock'n rollers, represented 'the ultimate domestication and feminization of the Beatles' ${ }^{3}$ Others works are more individualist, especially those focused on the group's main songwriters, reflecting, in Paul Du Noyer's phrase, the continuing 'dynastic rivalry between the houses of Lennon and McCartney' which extends to the respective restoration and presentation of the suburban homes in which they grew up. ${ }^{4}$

This essay transects these modes of recollection to chart the stories implicated in Strawberry Fields forever and Penny Lane, concentrating on the former recording. In addressing their status as autobiographical songs, the essay focuses on the landscapes of their life stories, especially the pastoral imagery of their suburban settings. ${ }^{5}$ It does so from a perspective which co-ordinates a critical space between past and present and between history and memory. This takes the form of two interpretative frames: closeups, focused on the production and reception of the record in 1966-67, using the contemporary press alongside subsequent memoirs, and wide-angled views, bringing together different kinds of information and different orders of experience (in one paragraph academic geography and avant-garde film-making) which are only evident in hindsight. ${ }^{6}$ This double perspective locates a nostalgic strain of Sixties pop culture both within a long tradition of pastoral sensibility and within the material transformations of the period. It specifies the pop single as a format at and for a particular moment, when a variety of intersecting, transatlantic developments (in songwriting, instrumentation, recording technology, radio air play and promotional marketing) enlarged and intensified the hit single's cultural scope and potential. ${ }^{7}$ In concentrating a range of concerns - private and public, lowbrow and highbrow, archaic and progressive, epic and everyday - the expressive power of these singles, by a number of recording artists (including Bob Dylan and the Kinks as well as the Beatles), to represent complex worlds arguably bears comparison with that of compressed formats in different media in other eras, such as Tudor sonnets and Georgian landscape engravings. ${ }^{8}$ As a mode of enquiry, current across the humanities, this essay focuses 'through the aperture of what might be called "the instance"".

The histories, formations and effects of culture are read from (as they were originally compressed into) a series of single entities (moments, events, texts, material objects) that have a specific historical or temporal locale... And its very temporal specificity provides... a window onto the domain of culture then, at that moment, and now, in our present of enquiry. ${ }^{9}$ 


\section{Pastoral landscape and pop culture}

Pastoral landscape has proved a powerful imaginative resource in western culture since antiquity, as a way of portraying stages of life, including childhood, courtship, parenthood and death, in such settings as parks, gardens, pasture and woodland. The politics of pastoral, the plotting of scenes from ideological perspectives, has been a powerful ingredient in views of Anglo-British landscape and culture. Different, sometimes conflicting ideological interests have staked their claims for pastoral landscape and shaped its imagery: socialist ramblers, folklorists and planners as well as tory gentry, painters and landscape gardeners. Consciously English pastoral, focused on claims to national identity, has proved a highly flexible, hybrid genre, drawing on both courtly and folk idioms and mixing musical, literary and graphic media. A range of works from orchestral music to architectural design expresses dissident as well as establishment values, deploys modernistic as well as archaic styles, looks forward as well as back, envisions darkness and disenchantment as well as sweetness and light, and evokes pastoral scenes not only in a variety of upland and lowland countryside but in towns and cities too. So powerful is pastoral as a landscape aesthetic that other sensibilities which seek to expose its illusions or partiality, from the perspective of harder places, such as the worlds of work or suffering, are conventionally defined as a counterpoint genre, mock-pastoral, or counter-pastoral. ${ }^{10}$

If classical pastoral landscape is a liminal zone outside the city, where villas and pleasure gardens open onto meadows and woodland groves, it is not surprising that suburbs have proved key sites of English pastoral. From the 18th century, consciously aesthetic residential and industrial developments have conserved old parkland trees and country lanes and parcelled former pasture for new garden plots. In response, a snobbish mock-pastoral literary tradition contrasts suburban dreams of the good life with grim actuality, often from the vantage point of an older, more mature-looking suburban landscape which appears now either as city or country. In more inclusive views, different classes of homes and gardens cohere as a pastoral scene and new forms of transport and communication give access to an older landscape history. Such is the view of The castles on the ground: the anatomy of suburbia (1946), written by J. M. Richards, editor of the modernist Architectural review and illustrated by neo-Romantic artist John Piper, a patriotic appraisal of that popular and critically derided suburban landscape, of interwar semi-detached houses on arterial roads. Fragments of older features (the gatepost of an estate lodge, a patch of ancient woodland, an arts and crafts villa converted to a council office) come into view as new developments are built, in a landscape for newly released leisure time, for various hobbies and pastimes, gardening, watercolour painting, cinema-going, or just revelling in the scent of asphalt and mown grass on a summer evening and reflecting in the deep quiet between the passing car lights, 'a fuller life of fantasy as well as fellowship'. ${ }^{11}$

This suburban scene currently exercises considerable cultural enchantment. It dominates the current political imagination. As modernizing Conservative Party strategists have invoked the 20th-century suburb as a pastoral myth of origin, to eclipse their older patrician image of county shire and country estate, so modernizing 
Labour Party strategists have invoked it too, to efface their older plebeian image of industrial regions and factory towns; thus New Labour policy architect Philip Gould locates his 'New Labour childhood' in Woking, Surrey, in the 1950s, 'where people lived in unassuming council estates or in tiny semi-detached houses ... neither privileged nor deprived ... a land of suburban dreams ... the land that Labour forgot' ${ }^{12}$ The suburban scene plays a powerful role in academic studies of 20th-century culture, especially of popular media. It occupies a central place in studies of white, mainly male-produced, English pop music, a mock-pastoral of domestic respectability to escape from, a deep pastoral world of childhood to return to. Shaped by the art school education and values of Sixties English pop, this suburban sensibility is a relational one, in which two imaginative geographies come together, suburbia and bohemia. These two worlds can appear opposed, as when suburban boredom, mass taste and respectability is caricatured from a cosmopolitan, artistic vantage point, or can appear integrated, with suburbs envisaged as creative, imaginative places, mixing high and low culture, conspicuous consumption and skilled enthusiasms. Teenagers roaming overgrown places at the edge of estates or playing music in the bohemia of the teenage bedroom are heirs to their grandparents in earlier suburban hymns, gathering blackberries, gardening and listening to the BBC Light Programme. ${ }^{13}$

Pastoral sensibilities assumed a powerful currency in English pop culture from the early Sixties in a new cultural arena which included a range of arts from painting, photography and design to high street fashion and hairdressing. While the pop arts expressed progressive values, in such realms as technology, social opportunity and consumerism, they also looked back, sometimes nostalgically, to an older country. ${ }^{14}$ Exchanges with American metropolitan culture (actual and imagined) in a variety of forms from comic books to rock'n roll served to re-vision Anglo-British culture, sharpened a sense of its landscape and heritage from both progressive and reactionary perspectives. $^{15}$

The works of Reyner Banham, architectural critic and leading pop theorist, express the most progressive, internationalist sensibility, affiliated with a commercial, masscultural axis: Hollywood-Detroit-Madison Avenue. ${ }^{16}$ Postwar Pop was 'the revenge of the elementary school boy' growing up 'in the pop belt' of 1930s, in 'the lived culture of a place like Norwich' (Banham's home city) enjoying American films and magazines as well as Shakespeare school plays. Here was the hybrid, hedonistic world which state interests like the $\mathrm{BBC}$ and Arts Council, and moralizing folk revivalists and literary critics like A. L. Lloyd and Richard Hoggart, wished to reform, in the name of 'serious' or 'popular' culture. Banham and his International Group circle of artists and designers were intent on renovating the pop belt and raising its lived culture as an arena of cultural analysis. ${ }^{17}$ It was Banham's very hostility to postwar Englishness, in all its variants, conservative and socialist, serious and whimsical (including the 'picturesque faction' on the Architectural review, which he helped edit) which led him to reappraise the country's cultural inheritance. He envisaged a pop environment in which 18thcentury landscape parks and paintings featured as prominently as tail-finned cars and transistor radios. 'I dig the landscape scene more than most art forms,' he told New Statesman readers in 1962. 'I have actually read two of Repton's Red Books in the 
original handwriting, I know all the temples and pavilions at Stowe (even the Fane of Pastoral Poetry) and I could probably take a party on a convincing conducted tour of Chiswick Park.' The assertion is directed against those scholars who claimed landscape parks as the creation of their aristocratic owners, whereas he looked to the professionalism and expertise of their designers, as he looked to that of Detroit car stylists, rock'n roll musicians or motel architects. ${ }^{18}$ Not all old sites found a place in Banham's pop environment. A refurbished Victorian relic like the Roundhouse in Chalk Farm, north London, the former railway building converted into an avant-garde performance space, was, he observed in 1964, 'the topographical symbol' of patronizing pop culture, sited between the 'eggheads of Hampstead' and the 'depressed minorities of Camden and Kentish Town'. ${ }^{19}$

The works of the painter Peter Blake expressed a more elegiac and patriotic pop sensibility, and had an increasing influence on the pop arts, especially music. From as modest a background as that of Banham (in Dartford, Kent), Blake's education and early career in art schools (including a period studying folk art in Europe), and his interests in what his progressive critics called 'rather archaic entertainments', such as circuses and music hall, made for a contrasting exchange with American culture. ${ }^{20}$ Selfportrait with badges (Figure 1) achieved instant celebrity when it won the 'junior prize' (for artists under 26) in the prestigious John Moore's painting competition in Liverpool in November 1961; the picture and the artist became highly publicized, notably in two other pop media: the first issue of the Sunday Times colour supplement in February 1962 and Ken Russell's film Pop Goes the Easel for the Sunday evening BBC arts programme Monitor broadcast the following month. ${ }^{21}$ While the American insignia in the painting attracted attention-the blue denim clothes, the basketball shoes, the badges of celebrities and consumer goods, the Elvis magazine in the artist's hand-it appeared a traditional image: 'painted in an old fashioned way,' noted the Listener; 'quaintly impressive,' observed the Times; 'peculiarly English,' concluded the Sunday Times. $^{22}$ Set in a garden, posed under a tree, the figure is a pop remake of Gainsborough's Blue boy, but without the swagger of that portrait; reserved, anxious, hemmed in, it looks back further to Tudor portraits of melancholic young men in pleasure grounds and forward to family snaps of schoolboys posed awkwardly in suburban gardens. ${ }^{23}$ The badges Blake sports include English ones, for I Spy, Poppy Day and vaudeville revival group the Temperance Seven; moreover the ones for American heroes, including the losing presidential candidate Adlai Stevenson, New York governor Fiorello LaGuardia (dead for 14 years), Pepsi Cola (America's second most famous drink) seemed dated; even the figure of Elvis in 1961, sanitized for a film career, had lost its provocation. ${ }^{24}$ The increasing publicity for Peter Blake included photographic shots of his house and garden in the (then) decaying aesthetic suburb of Bedford Park, West London, and his collection of Victorian toys, Edwardian pub signs and enamelled advertisements, and fairground dummies. ${ }^{25}$ "When many chose to interest themselves solely in Americana,' noted Topic magazine, 'Blake has occupied himself with the humbler home products. ${ }^{26}$

In incorporating humbler home products, Blake's work drew both on the work of an older generation of neo-Romantic artists and upon current transformations of the urban 


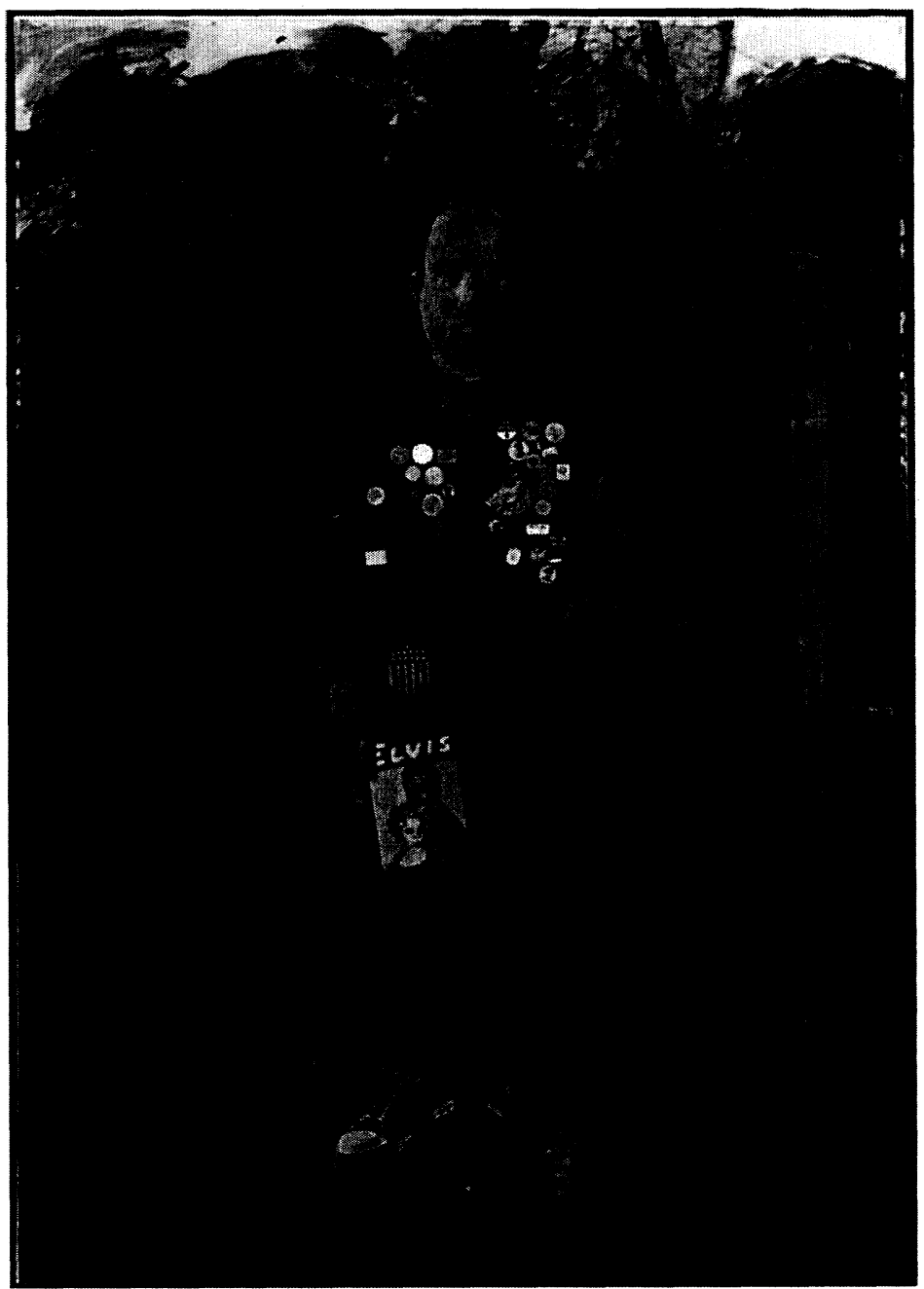

FIGURE 1 Peter Blake, Self-portrait with badges (1961). (CTate, London 2004; Peter Blake 2005. All rights Reserved, DACS.)

fabric accompanying the property boom. ${ }^{27}$ Extensive areas of Victorian and Edwardian London were either demolished to make way for new modernistic residential and commercial developments or gentrified for the new producers and consumers of pop culture. Possessions, fixtures and fittings cleared from old houses and shops filled street markets and antique shops with Anglicana, to furnish bohemian flats, provide props for photographic and film studios or material for artworks (Blake's Toy shop of 1962 is constructed from a salvaged shop window and door and filled with his own collection of old toys, some from his childhood). ${ }^{28}$ The clearance of some parts of old London only served to highlight the sites and scenes which remained. In charting developments 
in 1964 Hugh Prince noted that the gas lights, music halls and tramways had gone, only to focus attention on 'the slate-roofed semi-detached house, the suburban railway station and the Victorian church' in a preserved framework of parks: 'The peace and solitude of Green Park in the early morning, a flock of sheep placidly grazing in Hyde Park in summer sunshine, white clouds reflected in the Serpentine, the high open hills of Hampstead on a windy afternoon. ${ }^{29}$ The conjunction of modern, forward-looking structures with surviving and renovated aspects of the past is a defining motif of much visual art of the period, especially photography and film where it can take on a dark undercurrent. ${ }^{30}$ This is captured in Antonioni's Blow-up (1966), in which a fashionable photographer ventures into an area of London undergoing property development to take a series of pictures of what turn out to be murder scenes in a local park, Death in Arcadia. Entering an antique shop, he is asked what he is looking for. 'Pictures,' he replies, 'Landscapes.' Pointing to an old landscape painting, he is told none are available: 'Sold, all sold.'31

Writing in December 1966, in the first attempt to survey the shifting culture of the pop arts, to 'map out its ground', the Observer art and cultural critic George Melly noted that 'the Country of "Now" where everyone is beautiful and nobody grows old' was increasingly suffused with an eclectic nostalgia, typified by boutiques selling actual or fabricated antiques and memorabilia: Victorian military uniforms, Thirties suits, granny spectacles, chamber pots, Union Jack flags, 'a cool if deep chauvinism'. Melly used a Thirties concept to describe this, 'camp'. 'Camp in the pop sense implied "dated and/or ridiculous" and yet somehow available... it allowed pop to expand its terms of reference, its bank of images. ${ }^{, 32}$ London-based pop groups already displayed an almost archival connoisseurship for black American music (this obscure country blues 78 or that R\&B track), 'that middle-class knowledge,' recalled Mick Jagger, 'that sense of history and the desire to know everything. ${ }^{33}$ Camp both extended the repertoire of hit singles and repatriated the references, for example in 1966 'the music hall knockabout of the Kinks' Well Respected Man, the courtly farce of the Rolling Stones' Lady Jane'. ${ }^{34}$ Camp also signified the growing gentrification of pop culture; as Private Eye journalist Christopher Booker noted at the time, the classless new aristocracy of musicians, photographers, painters and designers were being reshaped by the values and imagery of an older, decidedly upper-class aristocracy. ${ }^{35}$

\section{A place to hide away}

From their beginnings as a professional group in 1961, the Beatles' musical range was wider and less purist than that of most London groups, including show tunes and country and western songs, and their references more consciously cultural than other beat groups in Liverpool, with a moody look fashioned in the art school bohemias of Liverpool and Hamburg and publicity photos taken in a picturesquely Victorian setting of decayed dockland and municipal parkland. ${ }^{36}$ The leaving of Liverpool for London, where they were taken up as key figures in the capital's pop pantheon, sharpened a sense of personal memory and literary history in the Beatles' work. Lennon's 
best-selling book In my own write drew on his own schoolboy surrealism, the notebooks he filled as a teenager with pastiches of Goon Show broadcasts and Edward Lear-style Nonsense verse, and was celebrated by his appearance at a Foyle's Literary Luncheon alongside George Bernard Shaw. ${ }^{37}$ On the basis of the book, a journalist asked Lennon, 'Why don't you put something of your childhood into your songs?' Lennon responded with an associative song about 'the places I remember', In my life. ${ }^{38}$ Changes in songwriting were part of the Beatles' transition from live performers to record makers, enabled by a favourable new contract with EMI, involving increasing time in the studios at Abbey Road. As Cook and Mercer have pointed out, the focus on recording rather than playing songs live, to be listened to, not danced to, made for more lyrical complexity, in the length and range of words, with proper names, of people and places, featuring increasingly in vignettes: Eleanor Rigby, Father Mackenzie, Dr Robert, Mr Wilson; Penny Lane, Bishopsgate, Blackburn, the Albert Hall. ${ }^{39}$ It also allowed Lennon and McCartney to activate the surreal wordplay that they grew up around, as a Liverpool vernacular as well as from books and radio broadcasts, if not so much the 'proletarian Scouse tradition of dockland funnymen,' notes Du Noyer, but that of 'the droll suburban sceptic, the Dale Street cotton clerk or low Tory stockbroker'. ${ }^{40}$ Liverpool-raised himself, George Melly noted:

\begin{abstract}
As James Joyce reconstructed the Dublin he had fled from, so the Beatles rebuilt the Liverpool of their own anonymous childhoods. I can vouch for the imaginative truth of 'Eleanor Rigby': the big soot-black sandstone Catholic churches with the trams rattling past, the redbrick terrace houses with lace curtains and holy-stones steps... [with] 'Yellow Submarine', the other side of the single, [they] pulled off something extraordinary - an instant nursery rhyme, as unselfconscious as a children's street song, but true to their own experience, to their own childhood.... It's not American comic heroes who climb aboard the Yellow Submarine but Desperate Dan or Lord Snooty and his pals. The departure for the 'Sea of Dreams' is from the Liverpool pierhead. ${ }^{41}$
\end{abstract}

The new cultural range was fostered by producer George Martin, who drew upon his experience recording a variety of artists including the Goons and the Temperance Seven to produce what he called 'sound pictures'. ${ }^{42} \mathrm{He}$ introduced instrumentation alluding to past musical idioms, the harpsichord-like electric piano solo of In my life, the harmonium accompaniment of We can work it out, the brass band of Yellow submarine. Many of Lennon and McCartney's melody lines, perhaps unwittingly, already had archaic aspects, such as the hymn-like cadences at the end of songs, but the folk-style modal scale of Eleanor Rigby (reminiscent of that of Scarborough Fair) combined with an austere string quartet arrangement produced a startlingly new chartbound sound, aligned to earlier, classically styled 20th-century English pastoral music. ${ }^{43}$

Released in June 1966, the Beatles' Paperback writer sent up literary London, namechecking the Daily Mail and 'the man named Lear'. The drone-like melody of its Bside, Rain, reflected the growing influence of Indian classical instrumentation (no less than harpsichords an entrée into an imperial past) and carried a faux naif, return to Eden lyric. ${ }^{44}$ In a patrician response to the parkland venue of the San Francisco psychedelic movement earlier in the year, the promotional film for both sides of the single placed the group in the 18th-century villa garden of Chiswick House, posed with 
their instruments among trees and statuary in the style of an 18th-century aristocratic portrait. ${ }^{45}$ Christmas 1966 saw the breaking of a seasonal tradition; there was no new Beatles LP, or at least not one with new songs, instead an album of previous hits, entitled $A$ collection of oldies (but goldies) which inaugurated a new tradition of pop's nostalgia for itself; its pastiche Edwardian cover art shows a louche King's Road dandy posing in front of a country house and luxury motor car heading for the hills. ${ }^{46}$

As the Beatles produced a new past as record makers, so they jettisoned their own past as live performers. The final world tour in 1966 was a musical disaster: the new songs were not playable on the group's conventional instruments and the old hits were performed perfunctorily in large stadia with inadequate amplification. The tour was a diplomatic disaster too, the group accused of snubbing the Marcos family in the Philippines and provoking record burnings in the United States' Bible Belt through Lennon's infamous 'more popular than Jesus' remark. For some months the group went into public exile, Harrison to India to study the sitar, McCartney to compose an orchestral film score for a nostalgically 'northern' film 'The family way' and Lennon to Almeria, Spain, to film his part as a British sergeant in a surreally satirical How I won the $w a r$, for which he donned wire-framed glasses like those he wore at primary school. ${ }^{47}$ Two of the group went underground too. McCartney was a prominent figure in the counter-cultural bohemia centred on the Indica bookshop in Bloomsbury, where New York artist Yoko Ono had her first London exhibition, and the underground newspaper IT (International Times) launched in October 1966 with an all-night event at the Roundhouse featuring a new group of posh architecture students, Pink Floyd, specializing in politely accented psychedelia. ${ }^{48}$

Lennon and McCartney rivalries still mark recollections of this period. While McCartney lived in a Georgian house filled with artworks in the smart inner suburb of St John's Wood, close to Abbey Road and a quick drive to Bloomsbury, Lennon was living a more domestic life in a 20th-century mock-Tudor mansion named Kenwood in the stockbroker belt of Weybridge, Surrey. 'I introduced John to Yoko through my own interest in the avant-garde,' McCartney claimed in 1988, 'John wasn't avant-garde till later. Then John became wildly avant-garde because he was so fucking constricted living out in Weybridge... It wasn't his wife's fault, she didn't understand how free he needed to be. ${ }^{49}$ George Martin agreed, reckoning that 'the atmosphere at Weybridge was not conducive to good songwriting ... when [John] wanted to escape suburbia he would drive up and spend the night at Paul's place. ${ }^{50}$ In 1970 Lennon remembered Kenwood differently, writing and recording songs, producing 'far out' tapes and $8 \mathrm{~mm}$ movies. ${ }^{51}$ Friends living nearby do too. In 1984 Pete Shotton recalled the tape loops and reverse recordings done in the studio as well as the new instruments like the mellotron, an electronic keyboard which played tapes programmed to imitate the sound of real instruments. ${ }^{52}$ 'I felt that Paul was mixing with an unconventional crowd, but he was very conventional,' observed Ringo Starr in 1992, 'whereas John was being unconventional at home. ${ }^{53}$

Lennon wrote Strawberry Fields forever on film location in Almeria in September 1966 and made demonstration tapes, accompanying himself on acoustic guitar, in Weybridge when he returned. The song was the first to be recorded when the Beatles 
assembled for a prolonged period of studio work at Abbey Road from late 1966 to the spring of 1967. The recording took place over a month, from late November to Christmas 1966, during which the song was reshaped several times and increased in instrumental and technological complexity. It was released in the UK, as a double-Asided single with McCartney's composition Penny Lane on 17 February $1967 .^{54}$

\section{Memory Lane}

In a record which prompted listeners to puzzle out its meaning, the place names in the title offered a main clue. In an exclusive preview Melody Maker informed its readers (inaccurately) that Strawberry Fields was a reform school and that Penny Lane was a road in north Liverpool. ${ }^{55}$ Advertisements for the record took the form of an aerial photograph or a map (Figure 2) on which the locations were pointed out, along with the birthplaces of all the group, panoramic views typical in Sixties films and television programmes of northern cities, some featuring lads looking back on the world they had left. ${ }^{56}$ In late March, by which time the lyrics were familiar, Record Mirror did a feature on the Penny Lane roundabout and shopping parade, finding the very barber's shop mentioned in the song and interviewing the barber, one Mr Bioletti, himself. ${ }^{57}$

The two place names were key sites in a process of charting the childhood worlds of Lennon and McCartney. Shortly after the record's release, novelist and journalist Hunter Davies, another northern boy made good in media London, began his research for the authorized biography of the Beatles, focused on their early youth, and based on interviews with friends and relations as well as the group. ${ }^{58}$ The recollections served to distinguish the group's songwriters and define the grounds of their partnership. Lennon was politely brought up by his aunt Mimi in a private semi-detached house in the

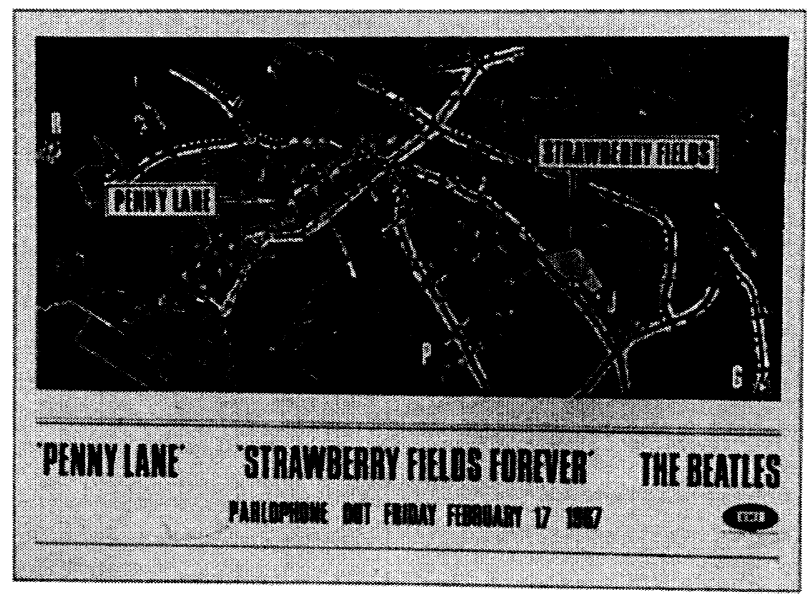

FIGURE 2 Advertisement for Strawberry Fields forever/Penny Lane, February 1967. (C) EMI Records Limited. Used with permission. All rights reserved.) 


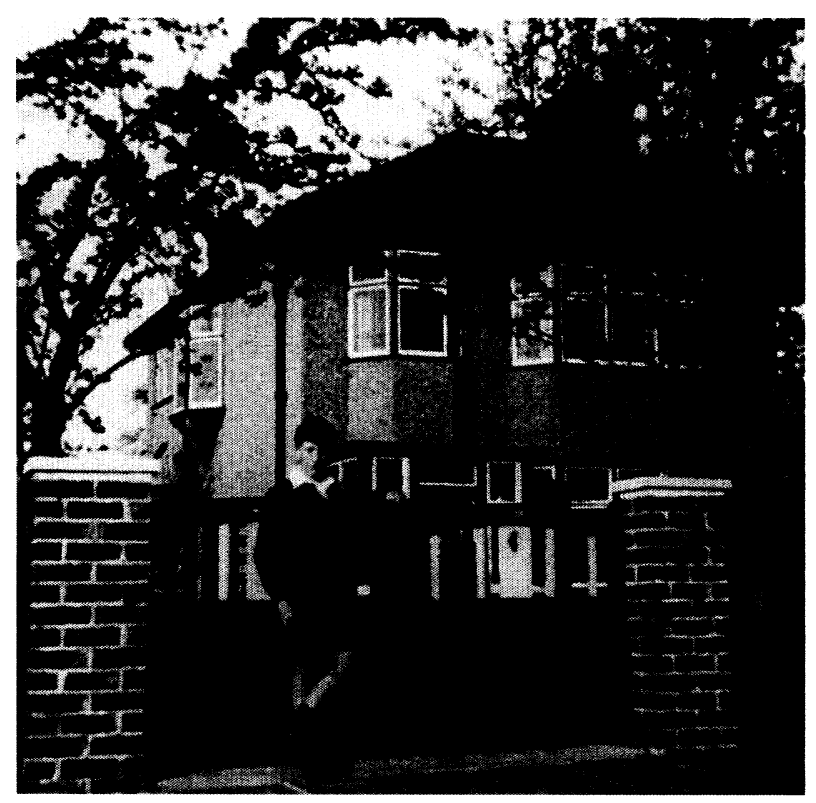

FIGURE 3 John Lennon aged 14, outside his Woolton home, 'Mendips'. (Private collection.)

former village of Woolton (Figure 3), a bookish and well-spoken child, singing in the church choir, who turned into that familiar figure, the teenage malcontent; McCartney grew up in a lower-class but more musical household, in a council house, across the municipal golf course, in Allerton; both inhabited a suburban world where they could find common ground, not least at the groups' own pastoral myth of origin, the 1957 Woolton church summer fete where McCartney was invited to join Lennon's skiffle group. This was a view echoed in the biography's harmonious image of the songwriters' current lives in 1967, McCartney the man about town in St John's Wood, Lennon happily married in Weybridge, coming together in the Abbey Road studios.

In subsequent memoirs, especially after the break-up of the Beatles, the reconstructions of Liverpool upbringings became more complicated. In the 1970 interview with Rolling Stone Lennon put on a tough 'working-class hero' persona, claiming an ancestry in Liverpool as a largely Irish, transatlantic dock city of the dispossessed. This underpinned his current choice to live in New York - 'I should have been born in New York, man. That's where I belong ... there might be a lot of dirt in the air, but this is where it's happening' - but, conventionally enough, in the next utterance it could provoke a pastoral response: 'I need to go bome, I need to look at the grass, I'm always writing about [the?] English garden and that lot.' In a post-psychedelic period of rock'n' roll revivalism, when he was producing stripped-down, almost imageless recordings, Strawberry Fields forever is recalled as a realist song, written from painful experience, but not located in a polite home upbringing. ${ }^{59}$ In the Playboy interview recorded in September 1980 during what he termed his 'house mother' period (an interview which 
has assumed commemorative status because it reached the news-stands in the same week as his death), when he was still living in New York but evidently homesick, even taking to wearing his old school tie, Lennon dwelt on this domestic upbringing. His recollections of his early upbringing echo those of his aunt (and that of much Romantic childhood literature) in remembering a precociously imaginative, if dreamily introspective child. ${ }^{60}$

The key section of the 1980 interview deals with what Lennon calls the Beatles memory lane trip'. This begins with In my life, which 'started out as a bus journey from my house on 250 Menlove Avenue, mentioning every place I could remember', including the tram sheds near Penny Lane, 'and it was ridiculous ... but then I lay back and these lyrics started coming to me about the places I remember.' As Steve Turner has recently noted, the memories are literary as well as personal, echoing Charles Lamb's 1798 poem on childhood haunts Old familiar faces, a mainstay of popular anthologies like Palgrave's golden treasury found in the 1950s on the shelves of respectable homes and schools. ${ }^{61}$ Strawberry Fields forever prompts further home reflections.

I moved in with my auntie, who lived in the suburbs in a nice semi-detached place with a small garden and doctors and lawyers and that ilk living around, not the poor slummy kind of image that was projected...I was a nice clean-cut suburban boy... And Strawberry Fields was just around the corner from that. It was an old Victorian house converted for Salvation Army orphans, and as a kid I used to go to their garden parties with my friends.

The Gothic orphanage loomed large, like a haunted House on the Hill, in interpretations of Strawberry Fields forever; but in the interview Lennon maintained that the song 'had nothing to do with the Salvation Army', and that the image of being the orphan 'was garbage'. ${ }^{62}$ Pressed about the name, Lennon said it denoted 'a real place' but 'I took the name as an image. You know it's like [Sondheim's musical] $A$ little night music was from that Magritte painting, a black tree with half a silver moon on it ... an image - Strawberry Fields forever.' The bookish household in which he grew up shaped his imagination, his aunt's Book of the Month anthologies of Oscar Wilde and Dylan Thomas, the art volumes on Whistler and Van Gogh, and his own children's books, especially The wind in the willows, the Just William stories and Lewis Carroll's Alice adventures. ${ }^{63}$

In 1984 Lennon's childhood friend Pete Shotton recalled that they spent more time in grounds of Strawberry Fields, by bunking over the back wall to play in the overgrown part of the grounds, than with their parents at the annual public garden parties close to the house. This was one of a number of high-walled grounds of Victorian villas in Woolton, some deserted (with the wartime break in building development) which the boys played in, resonating with the literary secret gardens they read about. ${ }^{64}$ Other literary allusions were layered on later. The alliterative 'forever' of the song title echoes the most famous 'forever' in English pastoral poetry, the corner of 'a foreign field' that is 'forever England' in Rupert Brooke's 1915 sonnet The soldier. Edwardian poetry and music was dense with place names selected for their pastoral imagery as well as location, a tradition renewed by the Sixties folk revival. ${ }^{65}$ If Beat and R\&B groups were keen to sing songs with American place names like Route 66 and Memphis, Tennessee, 
it was folk singers who sang songs with English place names like Ratcliffe Highway and Nottenum Town and those primary schoolchildren still made to sing songs like Strawberry Fair. These songs featured in anthologies like The Penguin book of English folk songs, first published in 1959 and reprinted throughout the Sixties, edited by Ralph Vaughan Williams and A. L. Lloyd, figures responsible for promoting folk song as a patriotic and socially worthy alternative to commercial pop music. ${ }^{66}$ In an early demo tape recorded at home the refrain goes, 'Let me take you back, to Strawberry Fields'; in studio takes this is changed to 'Let me take you down to Strawberry Fields'. This change in trajectory converts a personal, chronological recollection into a folk memory. The declension echoes the excursions of folk songs and pastoral lyrics, their sad refrains beckoning the listener down sunken lanes to various scenes of illusory enchantment, in the Penguin anthology Sandbank Fields, the Banks of the Sweet Primroses and the Lowlands low. ${ }^{67}$ In its final form, the refrain opens Strawberry Fields forever, and with no middle eight or instrumental solo, the song cleaves closely to the form of folk ballads.

The dream-like lyrics of Strawberry Fields forever are like archaeological fragments, bits of colloquial speech ('you know ... all right... not too bad') and what sound like snatches of Timothy Leary's psychedelic slogan and George Gershwin's lullaby Summertime ('tune in...living is easy'). There are recurrent echoes of Alice's adventures in Wonderland: 'Nothing is real... it doesn't matter... [it's] all wrong... I must be high or low ... It's getting hard to be someone ... cranberry sauce'. A canonical dream work of English literature, Alice's adventures in Wonderland also offered a structure for the song. ${ }^{68}$ The book begins, you'll recall, with the dream-child falling asleep on a wooded bank on a stupefying summer's day while her elder sister is reading her a boring book with 'no pictures or conversation'. In her dream, full of pictures and conversation, Alice follows the White Rabbit across a field and down the rabbit hole, 'before she found herself falling down what seemed to be a very deep well'. 'Down, down, down' she fell, passing fragments of a well-appointed home and schoolroom, including maps, pictures and a jar labelled 'orange marmalade' before landing by a tiny door which opened into the 'loveliest garden you ever saw'. ${ }^{69}$

As a boy, Lennon read the Alice stories so many times that he recited passages to his friends by heart and pastiched them in his own words and illustrations: 'I used to live Alice,' Lennon told Hunter Davies. ${ }^{70}$ The Alice books 'were like a Bible to us both,' recalls Pete Shotton, 'from a very early age... John's ultimate ambition was one day to "write an Alice himself",, 71 The centenary of Alice in Wonderland in 1965 prompted a resurgence of critical interest in the books with new editions and adaptions. Jonathan Miller's film version for BBC television sought to express the "pains and perils of growing up' in an atmosphere of gothic melancholy. ${ }^{72}$ In 1966 the literary critic Donald Rackin pointed out that the first version of Alice in Wonderland was called Alice's adventures underground, 'since, above all else, it embodied a comic horror-vision of the chaotic land beneath the man-made groundwork of western thought and convention'. Perhaps predictably, given the hallucinogenic effects of the pill Alice takes, the book was taken up as a canonical text of the underground movement. Grace Slick wrote White rabbit in 1966, released by Jefferson Airplane as an album track in the 
same month as Strawberry Fields forever. ${ }^{73}$ George Melly first took LSD when Strawberry Fields forever was released and observed that the record 'made me feel like Alice looking through the door in the wainscot to the garden beyond' ${ }^{74}$ In part to understand why the drug made her husband seem 'a little boy again', Cynthia Lennon decided to drop acid, and also likened it to 'an Alice in Wonderland experience', but a bad trip in a disintegrating marriage: 'I felt as if the bottom was falling out of my world. ${ }^{, 75}$

The music for Strawberry Fields forever amplifies the declension and vacillation of the lyric. In early demo tapes the song sounds like a country blues, with Lennon struggling to make the words fit the rhythm; as the song develops the music follows the meandering lyrics, as if in an Anglican psalm. The record opens with a conventional pastoral sound, a piping cadence played on the mellotron. ${ }^{76}$ As the vocal intones, 'Let me take you down', so the music plunges, the speed of the mellotron suddenly slowed and electric guitars dropping an octave. In the first take of the recording the song is rather sweet, a wistful vocal and mellifluous arrangement rising brightly at the end with an arpeggio on the mellotron. In the final version (spliced from two takes of different tempos and keys, one slowed to match, approximately, the other) the mood is darker, the relentless downward movement intensified by the various layered effects: the voice lowered by a semitone, heavy drumming, cellos, brass, and descending figures on electric guitar and a svaramandel (an Indian harp). A coda takes the form of a tape of the finale reversed, fading with a reveille figure on the piano, - an Alice-like awakening? ${ }^{77}$

The structure and imagery of Strawberry Fields forever contrast with those of Penny Lane, which was recorded immediately after the final remix and was evidently McCartney's response to Lennon's song. The vivid imagery of Penny Lane is a closer mimicry of the highly staged style of Magritte, an artist whose own interwar suburban surrealism was increasingly popular, at the time both through commercial exhibition (McCartney started collecting Magrittes in 1966) and reproduction. ${ }^{78}$ Beneath the blue suburban skies is a colourful pageant, the barber showing photographs of haircuts on offer as if they are portraits, the pretty nurse selling poppies, conscious of playing a role; it is raining as well as sunny, late autumn (Remembrance Day) as well as summer. The musical arrangement makes Penny Lane a distinctively McCartney song, the jaunty melody, high-lying bass guitar, soaring classical-style trumpet solo. ${ }^{79}$ It also has the clean sound McCartney admired in the Beach Boys' studio work Pet sounds (another suburban reminiscence). ${ }^{80}$ The refrain is cheerfully demotic, echoing playground songs, football terrace chants and charabanc singalongs. In style and subject, the view in Penny Lane is a public one, a meeting place and seen as it were from the upper deck of a bus, a highly defined, topographical panorama; it contrasts with the stumbling, downward path in Strawberry Fields forever into a more obscure, introspective, world. ${ }^{81}$ The songs refashion two complementary English scenic sensibilities, the prospect and the picturesque. ${ }^{82}$

The promotional film for television (shown in its entirety, if transmitted in black and white, on two editions of BBC's Top of the pops) mimicked some of the sonic techniques of the single, with reversed sequences and negative shots, and deployed 
some of the style of contemporary avant-garde performance art, although this was in some degree forced on the production because of a Musicians Union ban on miming. ${ }^{83}$ The effect was to loosen the Liverpool locale. The sequence for Penny Lane starts with street scenes, a few frames of landmarks in the actual Penny Lane (shot on a day trip by a crew without the group) intercut with footage of the Beatles in east London, around Angel Lane, Stratford, on horses and sporting scarlet hunting jackets. This sequence segues into footage of the group riding (inexpertly) through the archway of Knole Park, outside Sevenoaks, Kent.

Managed by the National Trust, although owned by the Sackville-West family, Knole Park has a long and complex cultural history, especially over claims to its landscape. ${ }^{84}$ Pressure for public access increased with a series of carnivalesque acts of trespass in the later 19th century. ${ }^{85}$ In Virginia Woolf's experimental novella Orlando (1928), the park becomes one of Bloomsbury's bohemian landscapes, a shifting space-time tableau to affirm Woolf's literary friend Vita Sackville-West's claim to the estate, the story pivoting on the enduring symbol of an old oak tree on a rise in the park. The scenes for Strawberry Fields forever (Figures 4 and 5) are similarly transgressive and conservative. They are shot in wintry dusk and darkness on a hill known as Echo Mount, because it was a vantage point for listening to was known in Tudor times as the 'musicke' of the deer hunt-the baying hounds and thundering horses, the huntsmen's halloos and horns. Kettle drums are scattered on the slopes; a piano is strung with wires to an oak tree. The main sequence, alluding both to the tree symbol of the song and to its

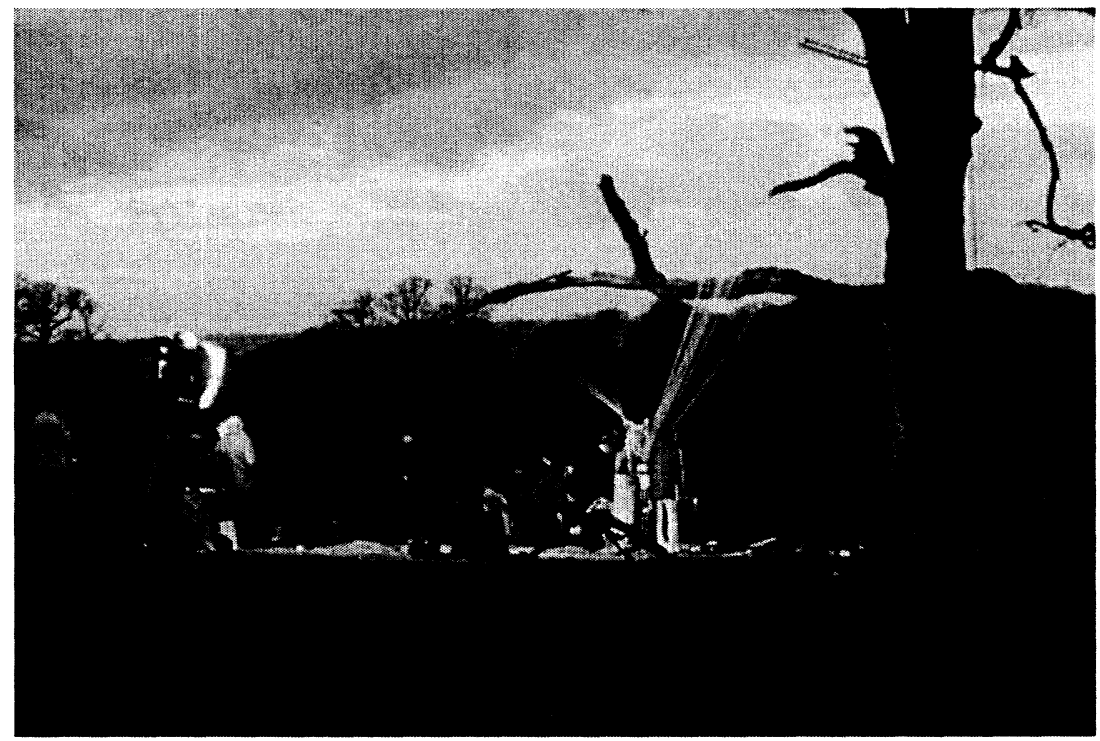

FIGURE 4 The Beatles filming at Knole Park, 30 January 1967 (CJane Bown, 27 April 2003: Guardian Newspapers Limited, 2003.) 


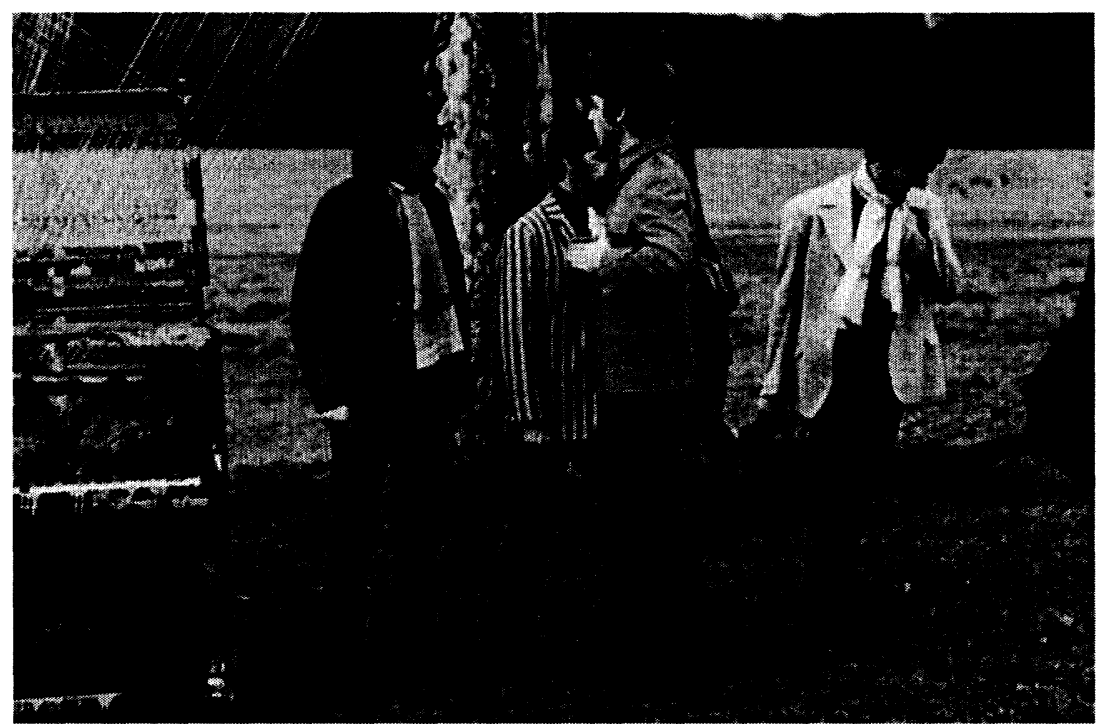

FIGURE 5 The Beatles 30 January 1967 at Knole Park, filming (CJane Bown, 27 April 2003: Guardian Newspapers Limited, 2003.)

reversed tape at the end, shows McCartney running backwards and leaping up onto a branch; as the record fades, the group daub the piano with paint.

\section{Way out}

The timing of the record's release served to increase its progressive aura, especially that of Strawberry Fields forever. Competing singles in the chart battle in the second week of February 1967, including Tom Jones's country-styled Detroit City and the Troggs' bigbeat Give it to me, seemed to the music press conservative by comparison. ${ }^{86}$ For New Musical Express the new Beatles record was their 'most way out single'; while the review recognized Penny Lane's 'catchy tune' and 'familiar falsettos' it didn't really know what to make of Strawberry Fields forever, if finding it 'more spellbinding with every play'. ${ }^{87}$ The reception was mixed, even within the same music paper. Running for 40 years, Melody Maker was consciously mature, aimed at practising or aspiring musicians as well as pop fans, carrying a large jazz section, columns by established musicians and job adverts for instrumentalists. The paper's senior editor, Ray Coleman, was a confidant of the Beatles, especially Lennon (whose biography he was to write) and secured a preview of the record. It described the 'swooping, deep, kaleidoscope of sound' of Strawberry Fields while noting that the song didn't 'tell a connected story', and recognized 'those familiar falsettos' in Penny Lane's 'urgent, colourful recollection of the Liverpool street that the Beatles remembered so clearly' ${ }^{88}$ Melody Maker was also the voice of manly resistance to psychedelic pop, 'a load of crap' according to the 
lead singer of the Move in his column; reviewing the new single, one of the Tremeloes announced that he hated both sides and predicted the Beatles would 'go down the pan'. ${ }^{89}$ It took the MM Mailbag's esteemed LP Winner, one Ian Clayton, 'jazz pianist, Romford, Essex', to raise the tone: 'The excellence of the latest Beatles single demonstrates their increasing ability to elevate the pop song to a more aesthetic and meaningful level, and yet retain its commercial essence. ${ }^{, 90}$

At the other end of the music press was Record Mirror, 'the largest-selling colour pop weekly', aimed at the new teenybopper market, a largely female readership keen on pin-up photos, celebrity gossip as well as records, whose pages were dominated by the Monkees, the made-for-television version of the Beatlemania image the Beatles themselves had shed. Record Mirror's senior editor, Peter Jones, gave the new Beatles single an attentive review, picking out the instrumentation which created the effects, the 'trumpet obligato' of Penny Lane as well as its 'sturdy beat'; 'play it, both sides' he advised his readers in somewhat schoolmasterly style, 'then study this well-constructed pop music'. ${ }^{91}$ Reader response was not encouraging. Miss Kim Sponswick of Guernsey couldn't get over the group's new appearance: 'Well, really, I was utterly ashamed of the Beatles on Top of the Pops, they looked absolutely disgusting with their moustaches. ${ }^{92}$ When the Beatles, for the first time, failed to reach the coveted number one spot (held at bay by Englebert Humperdinck's Release me and the new middle-aged market for hit singles), Record Mirror held 'an inquest. ${ }^{93}$ Columnist Jeremy Walsh concluded that Strawberry Fields forever was 'the most pretentious record the normally sensible Beatles have ever recorded', and that, while Penny Lane was a 'catchy pop record [it] should have been about love, emotion, happiness, unhappiness, not their home town'. The group showed a 'lack of attention to their fans'; 'the advocates of progressive pop are probably outrunning public tastes. ${ }^{94}$ Pictures of the Beatles recording showed them 'looking weirder in every photo'; it appeared EMI had 'hired the studio to the gypsies'. 95

National newspapers were just beginning to cover pop music. Don Short's weekly 'Discs' column in the tabloid Daily Mirror was devoted as much to celebrity gossip as to records, but his brief review of the Beatles' new single (under a feature on the men in Marianne Faithfull's life) found Penny Lane a 'knock out track' while 'the deeper thinking set may prefer Strawberry Fields forever'. ${ }^{96}$ Indeed, many of the deeper thinking set did. The BBC's classical music critic, Hans Keller, appeared on television to conduct the record with a bar-by-bar musicological commentary. ${ }^{97}$ Since identifying the 'pandiatonic clusters' and 'flat-submediant key-switches' in I want to bold your band, the Times music critic William Mann promoted the musical sophistication of the Beatles. In April 1967, in the same week as Record Mirror held their inquest on the chart failure of the Beatle's 'most pretentious record', the Times devoted an editorial to its cultural success. It discerned in the single 'a synthesis in which one of the strongest elements has been a powerful and probably instinctive Englishry hidden from the unobservant by electronic equipment; which goes back through Hymns ancient and modern to pastoral pentatonic tunes and other revitalized archaisms.' It was the 'simplicity, naturalness and the ordinary which might be a hopeful sign for the 
future...the ordinary world is worth attention...a commonplace suburb is a pleasanter source of inspiration than a psychedelic ecstasy. ${ }^{98}$

\section{Love Town}

If in the spring of 1967 Strawberry Fields forever and Penny Lane divided popular and critical opinion, by the summer the Beatles had recovered their cultural dominion with the subsequent recordings packaged in the album Sergeant Pepper's Lonely Hearts Club Band. In his biography of Lennon, Ray Coleman claimed this was to be a 'concept album', a day in the life of Liverpool children, but if so (and the claim has been disputed, principally by Paul McCartney) the plan was abandoned and the album is loosely themed as a burlesque band concert, a piece of King's Road camp. ${ }^{99}$ Released on 1 June, Sergeant Pepper was announced as 'a decisive moment in the history of western civilization' by the theatre critic Kenneth Tynan in the Times, and proved highly commercial, staying at number one in the album charts for 24 weeks. ${ }^{100}$ The cover art for Sergeant Pepper was as much a product of pop culture as the record. Brokered by gallery dealer Robert Fraser (a friend of McCartney), it was designed by Peter Blake and his wife, Jann Haworth, and staged at the Chelsea studios of photographer Michael Cooper (Figure 6). Blake posed the group as an old-fashioned military wind band in a park, their name picked out in a floral wreath, amidst a crowd

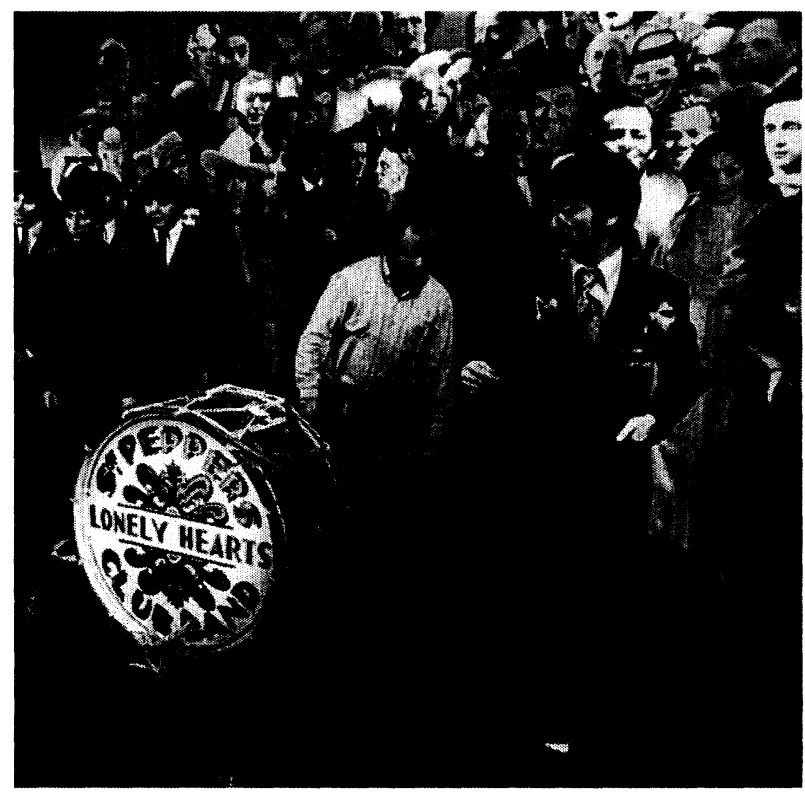

FIGURE 6 Peter Blake and John Lennon at the staging of the cover art for Sergeant Pepper's Lonely Hearts Club Band, 30 March 1967. (London Features International Ltd.) 
of cultural celebrities, including wax dummies of their earlier Sixties selves; Lewis Carroll, Bob Dylan and Jayne Mansfield are included, but not Elvis Presley, Chuck Berry or Buddy Holly. If the cast of screen actors, writers, gurus, musicians and designers mimics the pop pantheon of Sixties London, many are dead and the entire collage bears the impression of fashionably faded glamour. ${ }^{101}$

Sergeant Pepper provided the soundtrack to the Summer of Love. A range of music was restyled, with even the most obdurate of beat and mod groups being given a makeover, the Tremeloes appearing kaftaned, belled and beaded on Top of the pops and the Move's single Flowers in the rain inaugurating the BBC's first pop station, Radio 1. New places (Itchycoo Park, Blackberry Way) were added to the gazetteer of pastoral pop. Denmark Street caught on, the hacks of London's Tin Pan Alley penning psychedelic songs for fabricated groups like the Flower Pot Men; Carnaby Street caught up, boutiques outfitting weekend hippies who descended on the West End and returned to cavort in their local park. The underground scene continued, with groups named after picturesque sites like Tintern Abbey and Kippington Lodge, the latter in Kent, a new heartland of posh pop groups, reaffirming the county's claim to be the Garden of England. ${ }^{102}$ One hit single in the summer of 1967 managed to compress the cultural range of pastoral pop, at least its southern variant, into a wistful vignette. The Kinks' Waterloo sunset, a Thameside nocturne done in the style of a plaintive pub singalong, took the year's golden couple, Julie Christie and Terence Stamp, from their parts in the film of Thomas Hardy's Far from the madding crowd and transposed them from Wesssex to Waterloo, turning them into an everyday couple, Terry and Julie.

Psychedelic culture didn't travel well to the place the Beatles had left. Liverpool was 'not a Love Town', notes Du Noyer: bells and incense in the city were still largely the preserve of the Catholic Church; Liverpool in 1967 was 'a good place to come from, but not a groovy place to be'. ${ }^{103}$ The Beatles' imaginative geography of their home city appears to have reshaped an older-style pop culture which flourished when the group left for London in 1964. If Peter Blake's Self-portrait with badges (Figure 1) at the 1961 John Moores Exhibition had a powerful influence on the Liverpool art world, its leading figure, Adrian Henri, in using the city as a quarry for images and subjects, tried to create 'a sense of history' which was less nostalgic, and more political, than what he derided as 'Portobello Road' pop, with an older, beatnik style blend of jazz, poetry and avantgarde European literary allusions. ${ }^{104}$ George Melly had championed Henri and the other artists in the bohemian quarter of Liverpool 8; indeed, their harder-edged art provided some of the critical perspective of Melly's pop survey, Revolt into style. Henri and his younger compatriots, the poets Roger McGough and Brian Patten, came to metropolitan attention in 1967. ${ }^{105}$ Anthologized by the art critic Edward Lucie-Smith in a book titled The Liverpool scene, they were interviewed in IT the same week Strawberry Fields forever and Penny Lane were released. ${ }^{106}$ Henri's own poetry, published with McGough and Patten in the best-selling Penguin The Mersey sound (1967), repatriates the Beatles to a mock-pastoral city of local and international celebrities: 'Last night I met Paul McCartney in a suburban garden wearing a moustache drawn by Marcel Duchamp.' ${ }^{107}$ The usually staid Daily Telegraph was sufficiently intrigued to do a feature on 'the new culture of the Beat city'. The Liverpool Scene was 
enlisted as part of a regeneration initiative deploying its cultural capital to arrest its economic decline; in 1967 Henri worked with local activists on a Look at Liverpool trade exhibit showing the city's twin heritage of art and commerce, which was to travel to London, Paris 'and anywhere else the name of Liverpool now arouses interest'. ${ }^{108}$

Before the end of the decade, at least to the intelligentsia, pastoral pop appeared dated. 'Listening to Sergeant Pepper now,' noted George Melly in 1969, 'now that its electrifying novelty has worn off, what strikes me as interesting is that it is finally a celebration of the past with its certainties and simplicities'; the Beatles 'display little enthusiasm for the way we live now'. 'Well that passed off, as they say in Liverpool,' he concluded. Pop had been 'whimsical and pretty for too long [but] the blues were back ... even a short burst of Rock'n Roll ... the Stones shook themselves ... everything became tougher again - tougher and better. ${ }^{109}$ In this counter-pastoral climate, the Beatles were chided for their escapism, for their 'repeated flights into the past', in the words of Michael Wood in New Society, writing in the revolutionary summer of 1968, the group expressed 'the good child's hostility to grown ups', not that of street fighting men, mods 'breaking up Margate' or students 'digging up Paris'. ${ }^{110}$

\section{Theatres of memory}

In 1994 Raphael Samuel deployed the Renaissance idea of a memory theatre, a metaphorical and sometimes material space where the art of memory is articulated, to describe interconnections of past and present in contemporary culture. ${ }^{111}$ The idea is theoretically appealing, not only for showing how the art of memory is historically conditioned but also for showing that performance and representation are necessarily connected, that the art of memory enacts a world in the present as it represents the past. Recent geographical studies of memory focused on music may be framed in terms of various theatres of memory: the public, open-air rituals of Remembrance Day, with the sequence of hymns, brass bands, bugle solo and interval of silence, and the private acts of memory in homes where, as part of the routines of domestic life, recorded music induces moods of personal nostalgia and reminiscence, a Frank Sinatra tape the memory of an interviewee's mother, a Beatles CD track, In my life, another's father (even if he actually 'hated John Lennon'). ${ }^{112}$ The memory theatre of the Beatles heritage industry, both in Liverpool and beyond, accommodates modern forms of pilgrimage, with a key shrine at the Strawberry Fields memorial garden in New York's Central Park. ${ }^{113}$ These studies represent the culture of mourning and melancholy in current memory research. ${ }^{114}$

Sixties pop culture of the kind I have described in this essay, with its highly staged sense of the world - both as a scene in which music and art are produced and consumed and as one projected in the work - produced its own memory theatre. ${ }^{115}$ In charting its pastoral strain, this essay has explored its melancholy side, but described a theatre which plays comedy and history as well as tragedy, with productions of pantomime and farce. ${ }^{116}$ While some critics reckon that the lights have gone out on a golden age of pop music in the mid-Sixties (for it was a moment of astonishingly rapid 
development, when the music looked forward as well as back), pop's moment, as Jon Savage has emphasized, is a migratory one, realized in other times and places - not so much a period piece as a historical refrain.

Pop is where the private sphere of emotions and memory intersects with the public world of media, news, politics. Here, the stuff you can control jostles with the stuff you can't. That's why it's possible to construct social histories around pop. That's how many people remember things: not by what the politicians were saying, but by what music they were exposed to at any given time. ${ }^{117}$

\section{Acknowledgements}

Earlier versions of this essay were given as seminar papers to the Institute of Popular Music, University of Liverpool, the London Historical Geography series, the Department of Geography, King's College, London, and School of Geography, University of Nottingham. I wish to thank participants on those occasions, and the following for comments on written versions: Denis Cosgrove, Andrew Leyshon, David Matless and George Revill and Jay Sleeman. Further research, with Georgina Couch, was undertaken for the National Trust guide to John Lennon's childhood home 'Mendips'. Mike Heffernan and Jessica Dubow helped with the first line of this essay, which triggered the final version. This has benefited from conversations with Georgina Endfield and recommendations by editor Phil Crang and the two referees.

\section{Notes}

${ }^{1}$ On the process of conflation in the contemporary culture of memory see A. Huyssen, Present pasts: urban palimpsests and the politics of memory (Stanford, University of California Press, 2003), pp. 1-10; P. Middleton, 'The new memoryism: how computers changed the way we read'; New formations 50 (2003), pp. 57-74.

2 P. Du Noyer, Liverpool: wondrous place: music from Cavern to Cream (London, Virgin Books, 2002), p. 17; H. Davies, “"There's a place": 20 Forthlin Road', National Trust magazine 85 (1998), pp. 27-29; National Trust, Mendips (London, National Trust, 2003).

${ }^{3}$ G. Burns, 'Refab Four: Beatles for sale in the age of video', in I. Inglis, ed., The Beatles, popular music and society: a thousand voices (Basingstoke, Macmillan, 2000), p. 185.

${ }^{4}$ Du Noyer, Liverpool, p. 229.

5 S. Daniels and C. Nash, 'Lifepaths: geography and biography', Journal of historical geography 30 (2004), pp. 449-58.

${ }^{6}$ My interpretive language here owes something to a paragraph on $\mathrm{p} . \mathrm{x}$ of the introduction to R. Samuel, Theatres of memory, vol. I: Past and present in contemporary culture (London, Verso, 1994), and echoes sentiments in the introduction to Huyssen, Present pasts, pp. 1-10.

7 J. Savage, 'That's how good it is', introduction to H. Kureishi and J. Savage, eds, The Faber book of pop (London, Faber \& Faber, 1995), pp. xvii-xxxiii.

${ }^{8}$ On Georgian landscape engravings see S. Daniels, 'Reforming landscape: Turner and Nottingham', in P. de Bolla, N. Leask and D. Simpson, eds, Land, nation and culture 
(London, Palgrave, 2005), pp. 12-36; on sonnets, S. Greenblatt, Will in the world: how Shakespeare became Shakespeare (London, Cape, 2004), pp. 226-55.

9 P. de Bolla, N. Leask and D. Simpson, 'Introduction', to de Bolla et al., Land, nation and culture, pp. 6-7.

10 J. Dixon Hunt, ed., The pastoral landscape (Washington, DC, National Gallery of Art, 1992); S. Daniels, Fields of vision: landscape imagery and national identity in England and the United States (Cambridge and Princeton NJ, Polity Press and Princeton University Press, 1993); D. Matless, Landscape and Englishness (London, Reaktion, 1999); G. Revill, 'The lark ascending: monument to a radical pastoral', Landscape research 16 (1991), pp. 9-19; G. Revill, 'English pastoral: music, landscape, history and politics', in I. Cook, D. Crouch, S. Naylor and J. R. Ryan, eds, Cultural turns/geograpbical turns: perspectives on cultural geography (Harlow, Pearson Education, 2000), pp. 140-58; J. Barrell and J. Bull, The Penguin book of English pastoral verse (London, Allen Lane, 1974), pp. $1-7$.

$11 \mathrm{~J}$. M. Richards, The castles on the ground: the anatomy of suburbia (London, Architectural Press, 1946); S. Daniels, 'Suburban prospects', in N. Alfrey, S. Daniels and M. Postle, eds, Art of the garden (London, Tate, 2004), pp. 22-30.

12 P. Gould, The unfinished revolution: how the modernisers saved the Labour Party (London, Abacus, 1998), pp. 1-17. My thanks to Charles Pattie for this reference. On Tory uses of suburbia see D. Gilbert and R. Preston, "Stop being so English": suburban modernity and national identity in the twentieth century', in D. Gilbert, D. Matless and B. Short, eds, Geographies of British modernity: space and society in the twentieth century (Oxford, Blackwell, 2003), pp. 187-203.

13 J. Savage, England's dreaming: the Sex Pistols and punk rock (London, Faber \& Faber, 1991), pp. 1-11; M. Bracewell, England is mine: pop life from Wilde to Goldie (London, HarperCollins, 1997); S. Frith, 'The suburban sensibility of British rock and pop', in R. Silverstone, ed., Visions of suburbia (London Routledge, 1997), pp. 269-79; D. J. Taylor, 'The sound of the suburbs: the idea of the suburb in English pop', in R. Webster, ed., Expanding suburbia: reviewing suburban narratives (New York, Berghahn, 2000), pp. 161-72; J. Connell and C. Gibson, Sound tracks: popular music, identity and place (London, Routledge, 2003), pp. 74-79. On the imaginative geography of bohemia see E. Wilson, Bobemians: the glamorous outcasts (London, I. B. Tauris, 2000).

14 S. Rycroft, 'The geographies of Swinging London', Journal of historical geography 28 (2002), pp. 566-88; S. Rycroft, 'Mapping underground London', Cultural Geographies 10 (2003), pp. 84-111. These pioneering articles on the cultural geography of Sixties pop culture emphasise its progressive and radical currents but also identify old-fashioned elements such as aristocratic pageantry.

15 D. Brauer, 'British pop art 1956-66: a documentary essay', in D. Brauer, J. Edwards, C. Finch and W. Hopps, eds, Pop art US/UK connections (Houston, Merrill Collection, 2001), pp. 5487; C. Finch, 'London pop recollected', in ibid., pp. 20-42.

16 L. Lippard, with contributions by L. Alloway, N. Marmer and N. Calas, Pop art (London, Thames \& Hudson, 1969), pp. 31-40 (these pages are from a chapter on British pop art by Alloway).

${ }^{17}$ N. Whiteley, Reyner Banbam: bistorian of the immediate future (Cambridge, MA: MIT Press, 2002), pp. 11-28, 91-93, 379.

18 R. Banham, 'Kent and Capability', New Statesman 64 (7 December 1962), pp. 842-43, repr. in R. Banham, A critic writes: essays by Reyner Banbam (Los Angeles, University of California Press, 1996), pp. 87-90. 
19 Whiteley, Reyner Banbam, p. 379.

${ }^{20}$ Lippard et al., Pop art, p. 200.

21 'Pioneer of Pop Art', Sunday Times colour magazine (4 Feb. 1962); Pop goes the easel, Monitor, BBC Television (25 Mar. 1962).

22 Listener (30 Nov. 1961); Times (15 Nov. 1961); Sunday Times (2 Feb. 1962). My thanks to Alex Kidson for letting me see the press cuttings file at the Walker Art Gallery, Liverpool.

23 On melancholic portrait paintings see S. Daniels, Joseph Wright (London, Tate, 1999), pp. 23-24; on family snaps see $\mathrm{D}$. Chambers, 'Family as place: family photograph albums and the domestication of public and private space', in J. M. Schwartz and J. R. Ryan, eds, Picturing place: photography and the geographical imagination (London, I. B. Tauris, 2003), pp. 96114.

${ }^{24}$ S. Sellers, 'Caro verbum factus est: British art in the 1960s', in B. Moore-Gilbert and J. Seed, eds, Cultural revolution? The challenge of the arts in the 1960s (London, Routledge, 1992), pp. 255-78; J. Jones, 'Portrait of the week', Guardian (2 Feb. 2002). The picture also serves to re-vision English views of American pop art, recognizing products such as Superman, Coca Cola and Campbell's Soup as icons of the Thirties. See D. McCarthy, Pop art (London, Tate, 2000), pp. 58-64.

25 B. Robertson, J. Russell and Lord Snowdon, Private view (London, Nelson, 1965), pp. 274-77.

26 Topic (11 Dec. 1961).

27 Lippard et al., Pop art, pp. 28-32; C. Stephens and K. Stout, eds, Art and the 60s: This was tomorrow (London, Tate, 2004), pp. 19-21.

${ }^{28}$ Samuel, Theatres of memory, p. 93.

29 H. C. Prince, 'North-west London 1864-1914', 'Parks and parkland', in J. T. Coppock and H. C. Prince, eds, Greater London (London, Faber \& Faber, 1964), pp. 139, 337.

30 M. Bracewell, 'Swinging back', Frieze 32 (1996), pp. 25-27.

31 Blow-up: a film by Michelangelo Antonioni (London, Lorimer, 1971), p. 49. On arcadian London see D. A. Mellor and L. Gervereau, The sixties: Britain and France 1962-73 (London, Philip Wilson, 1977), pp. 13-21; R. Hewison, Too much: art and society in the Sixties (London, Methuen, 1986), pp. 69-73.

32 G. Melly, Revolt into style: the pop arts in Britain (London, Allen Lane, 1970), pp. 6-8, 160-61.

33 Du Noyer, Liverpool, pp. 91-92.

${ }^{34}$ J. Savage, 'The new naturalists', Mojo (Sep. 2004), pp. 114-15.

35 C. Booker, The neophiliacs: a study of revolution in English life in the fifties and sixties (London, Collins, 1969), pp. 18-26.

36 The Beatles, The Beatles anthology (London, Cassell, 2000), pp. 40-110; P. Trynka, ed., The Beatles: ten years that shook the world (London, Mojo, 2004), pp. 10-91; S. Frith and $\mathrm{H}$. Horne, Art into pop (London, Methuen, 1987), pp. 80-81.

37 R. Coleman, Lennon: the definitive biography ( London, Pan, 2001), p. 350.

38 G. Barry Golson, ed., The Playboy interviews with Jobn Lennon and Yoko Ono (New York, New English Library, 1981), pp. 129-30.

39 G. Cook and N. Mercer, 'From me to you: austerity and profligacy in the language of the Beatles', in Inglis, The Beatles, pp. 87-104.

${ }^{40}$ Du Noyer, Liverpool, pp. 4, 141, 195. The surreal style is typified by Liverpool comedian Ken Dodd.

${ }^{41}$ Melly, Revolt into style, pp. 79-80. 
42 Interview with George Martin in Record Mirror (27 May 1967); G. Martin with W. Pearson, All you need is ears (London, Macmillan, 1979); J. Tobler and S. Grundy, The record producers (London, BBC, 1983), pp. 108-23; P. McCabe and R. B. Schonfeld, Apple to the core: the unmaking of the Beatles (London, Sphere, 1973), pp. 77-78.

43 'Howard Goodall's 20th century greats', BBC 2 (27 Oct. 2004). Simon and Garfunkel's version of Scarborough Fair released as an album track in 1967 is based on a mid-Sixties arrangement of the song by Martin Carthy.

${ }^{44}$ I. MacDonald, Revolution in the head: the Beatles records and the sixties (London, Pimlico, 1994), pp. 157-58.

${ }^{45}$ M. Lewisohn, The complete Beatles chronicle (London, Chancellor Press, 1992), p. 222. On the geneaology of this portrait imagery see R. Leppert, Music and image: domesticity, ideology and socio-cultural formation in eighteenth-century England (Cambridge, Cambridge University Press, 1988)

${ }^{46}$ M. O'Gorman, 'Strange fruit', in Trynka, The Beatles, p. 248.

47 P. Norman, Shout! The true story of the Beatles (London, Elm Tree, 1981), pp. 250-73; Trynka, The Beatles, pp. 208-35; The Beatles, The Beatles anthology, pp. $200-237$

48 J. Green, Days in the life: voices from the English underground, 1961-1971 (London, Heinemann Minerva, 1988), pp. 74-137; P. Fryer, 'A map of the underground: the flower power structure and London scene', Encounter (Oct. 1967), pp. 7-20. On IT see Rycroft, 'Mapping underground London,' pp. 88-91.

49 Green, Day in the life, p. 79.

50 Martin, interview.

51 J. S. Wenner, Lennon remembers: the full 'Rolling Stone' interviews from 1970 (London, Verso, 2000), p. 60.

52 P. Shotton and N. Schaffner, John Lennon in my life (Sevenoaks, Coronet, 1984), pp. 101, 122.

${ }^{53}$ From an unused tape for ITV's South Bank Show, 'The making of Sergeant Pepper', quoted in G. Martin with W. Pearson, Summer of love: the making of Sergeant Pepper (London, Macmillan, 1994 ), p. 72

54 The various takes are available on several bootlegs, the fullest set on The Beatles, Notbing is real: the making of Strawberry Fields forever (Chapter One, 1992). Day-by-day documentation is in M. Lewisohn, The complete Beatles recording sessions (London, Hamlyn and EMI, 1989), pp. 87-90.

55 Melody Maker (28 Jan. 1967).

56 The version with an aerial photograph is in Record Mirror (18 Feb. 1967). On this panoramic sensibility see S. Daniels and S. Rycroft, 'Mapping the modern city: Alan Sillitoe's Nottingham novels', Transactions, Institute of British Geographers 18 (1993), pp. 460-80.

57 Record Mirror (4 Mar. 1967).

58 H. Davies, The Beatles: the authorized biography (London, Heinemann, 1968); H. Davies, 'Paperback writer', in Trynka, The Beatles, p. 247.

59 Reprinted as Wenner, Lennon remembers, first published in the UK by Penguin Books in 1973. Quotations taken from the recent Verso edition, 2000, pp. 144-45.

${ }^{60}$ Golson, The Playboy interviews; Du Noyer, Liverpool, p. 228.

${ }^{61}$ Golson, The Playboy interviews, pp. 129-30; S. Turner, A bard day's write: the stories bebind every Beatles song (London, Carlton, 2000), pp. 118-20.

62 Indeed, the most recent authoritative critic, Ian MacDonald, describes the vocal as the confused cry of 'an orphan at Strawberry Fields': Revolution in the bead, p. 172.

${ }^{63}$ Golson, The Playboy interviews, pp. 132-36. 
${ }^{64}$ Shotton and Schaffner, Jobn Lennon, pp. 28-29.

65 R. Stradling, 'England's glory: sensibilities of place in English music 1900-1950', in A. Leyshon, D. Matless and G. Revill, eds, The place of music (London, Guilford, 1998) pp. 177-96.

${ }^{66}$ R. Vaughan Williams and A. L. Lloyd, eds, The Penguin Book of English folk songs (Harmondsworth, Penguin, 1968); A. L. Lloyd, Folk song in England (London, Lawrence \& Wishart, 1967); Revill, 'The lark ascending'; G. Boyes, The imagined village: culture, ideology and the English folk revival (Manchester, Manchester University Press, 1994); D. Harker, Fakesong: the manufacture of British 'folksong' from 1800 to the present day (Milton Keynes, Open University Press, 1985), pp. 231-53.

${ }^{67}$ Vaughan Williams and Lloyd, English folk songs, pp. 18, 17, 106.

68 W. Empson, Some versions of pastoral (London, Chatto \& Windus, 1935), pp. 253-94.

69 L. Carroll, Alice's Adventures in Wonderland and through the looking glass: the centenary edition, ed. H. Haughton (Harmondsworth, Penguin, 1998), pp. 9-12.

70 Davies, The Beatles, p. 11.

71 Shotton and Schaffner, John Lennon, p. 33.

72 Broadcast on BBC 113 Oct. 1965 and 6 July 1966. Miller quoted at www.aliceinwonder land.fsnet.co.uk/film-tv-miller, accessed 21 Dec. 2003.

73 R. Philips, Aspects of Alice: Lewis Carroll's dreamworld as seen through the critics' looking glass, 1805-1971 (Harmondsworth, Penguin, 1971), pp. 452-88. For other Carrollinfluenced Lennon songs see also M. E. Roos, 'The walrus and the deacon: John Lennon's debt to Lewis Carroll', Journal of popular culture 18 (1984), pp. 19-29.

${ }^{74}$ Melly, Revolt into style, pp. 80-81.

75 C. Lennon, A twist of Lennon (London, Star, 1978), p. 181.

76 The sound is reminiscent of the pipe organ revived for folk music by Shirley and Dolly Collins: D. Laing, K. Dallas, R. Denselow and R. Skelton, The electric muse: the story of folk into rock (London, Methuen, 1975), p. 146.

77 The information in this paragraph is based on the bootleg Notbing is real and the Beatles CD Anthology 2, Disc 2, Tracks 1-3, and analyses of the record in W. Mellers, Twilight of the gods: the Beatles in retrospect (London, Faber \& Faber, 1976), pp. 84-5; MacDonald, Revolution in the head, pp. 170-75; W. Everett, The Beatles as musicians: Revolver through Anthology (New York, Oxford University Press, 1999), pp. 75-84; Martin and Pearson, Summer of love, pp. 14-23.

78 B. Miles, Paul McCartney: many years from now (London, Vintage, 1998), pp. 264-6.

79 McDonald, Revolution in the bead, pp. 177-79.

80 B. Golden, The Beach Boys: Southern California pastoral (San Bernardino, CA, Borgo Press, 1976), pp. 32-35.

81 Miles, Paul McCartney, p. 17.

82 Daniels, 'Suburban prospects', pp. 22-23.

83 Lewisohn, The complete Beatles chronicles, p. 243. Produced by Tony Bramwell for Subafilms, one of the Beatles' two film companies, the film was directed by Peter Goldmann, whose main work was on pop programmes for Swedish TV. Goldmann was clearly influenced by Dick Lester's use of (musical) non-performance in his Beatles feature films, as some early promotional videos show. See the interview with Goldmann in New Musical Express (18 Feb. 1967). Also B. Neaverson, The Beatles movies (London, Cassell, 1997), pp. 39-40. The art performance element owes much to the mid-Sixties Fluxus group, with which Yoko Ono was associated. See T. Kellein, Fluxus (London, Thames \& Hudson, 1995).

${ }^{84}$ National Trust, Knole Park (London, National Trust, 1998). 
85 D. Killingray, 'Rights, "riot" and ritual: the Knole Park access dispute, Sevenoaks, Kent, 188385', Rural bistory 5 (1994), pp. 63-79.

86 The working-class regional accents (south Wales and Somerset respectively) of Tom Jones and the Troggs placed them decidedly outside the art school orbit of metropolitan pop.

${ }^{87}$ New Musical Express (18 Feb. 1967).

${ }_{88}$ Melody Maker (11 Feb. 1967).

89 Ibid. (28 Jan. 1967; 11 Feb. 1967). The Move's singer was Carl Wayne, the Tremeloes' Alan Blakeley. For the Move and the Tremeloes in the 1960s see P. Hardy and D. Laing, The Faber companion to 20th-century popular music (London, Faber \& Faber, 1990), pp. 572-3, 635.

90 Melody Maker (4 Mar. 1967).

91 Record Mirror (11 Feb. 1967).

92 Ibid. (18 Feb. 1967).

93 This was the BBC's official chart of charts; the Beatles did reach number one in Melody Maker's chart.

94 Record Mirror (1 Apr. 1967).

95 Ibid. (8 Apr. 1967).

96 Daily Mirror (9 Feb. 1967).

97 This may have been a slot on the early evening magazine programme Tonight. I cannot recall exactly when, and have failed to find out, but the appearance is confirmed in D. Cooke, 'The Lennon-McCartney songs,' Listener (1 Feb. 1968).

98 E. Thomas and D. Gutman, eds, The Lennon companion: twenty-five years of comment (Basingstoke, Macmillan, 1987), pp. 109-13.

99 Coleman, Lennon, p. 556.

100 Quoted in K. Negus, Popular music in theory (Cambridge, Polity Press, 1996), p. 155.

101 Samuel, Theatres of memory, pp. 341-42.

102 S. Whiteley, The space between the words: rock and counter-culture (London, Routledge, 1992), pp. 61-81; A. Clayton, John Lennon (London, Sanctuary, 2003), p. 148; R. Chapman, 'Pot-head revisited', Mojo (June 1997), pp. 42-55.

103 Du Noyer, Liverpool, pp. 90-96.

104 P. Davies, Liverpool seen: post-war artists on Merseyside (Bristol, Radcliffe Press, 1992), p. 145; A. Brighton, 'The John Moores and its critics', in Walker Art Gallery, Jobn Moores Liverpool Exbibition 18 (Liverpool, National Museums and Galleries on Merseyside, 1993); Adrian Henri: paintings 1953-1998 (Liverpool, National Museums and Galleries on Merseyside, 2000), pp. 8-13.

105 Du Noyer, Liverpool, pp. 93-97.

106 E. Lucie-Smith, The Liverpool scene (London, David Carroll, 1967); IT (International Times). (13-26 Feb. 1967).

107 A. Henri, R. McGough and B. Patten, The Mersey sound (Harmondsworth, Penguin, 1967), p. 29.

108 Du Noyer, Liverpool, pp. 92-93; J. Willett, Art in a city (London, Methuen, 1967), pp. 271-75. For Liverpool University's participation in this concern to arrest decline at the time, in a project eventually funded by the Social Science Research Council, see R. Lawton and C. M. Cunningham, eds, Merseyside: social and economic studies (Harlow, Longman, 1970).

109 Melly, Revolt into style, p. 115.

110 M. Wood, 'John Lennon's schooldays', New Society (27 June 1968), repr. in Thomson and Gutman, The Lennon companion, pp. 145-49.

111 Samuel, Theatres of memory, pp. vii-x. 
112 D. Marshall, 'Making sense of remembrance', Social and cultural geography 5 (2004), pp. 37-54; B. Anderson, 'Recorded music and practices of remembering', Social and cultural geography 5 (2004), pp. 3-19.

113 R. J. Krase II, 'Imagining Strawberry Fields as a place of pilgrimage', Area 35 (2003), pp. 15462; see also the excerpt of a 1996 study by B. Wheeller in Connell and Gibson, Sound tracks, pp. 226-28.

114 This traumatic strain is central to works reviewed in S. Legg, 'Memory and nostalgia', Cultural geographies 11 (2004), pp. 99-107; see also the articles collected in New formations 50 (2003), particularly R. Luckhurst, 'Traumaculture', pp. 29-47, and A. Gibson, 'Oublier Baudrillard: melancholy of the year 2000', pp. 123-41. Memory is heavily, sometimes traumatically, evident as a deep stratum of myth in Simon Schama's 1995 book and television series Landscape and memory. (London, Harpercollins 1995)

115 J. Green, All dressed up: the sixties and counter-culture (London, Pimlico, 1999).

116 For an example of traumatic pop history see D. McKinney, Magic circles: the Beatles in dream and bistory (Cambridge, MA, Harvard University Press, 2003), a response to being born in 1966 in Waterloo, Iowa, 'too young to remember the sixties; too old for them not to loom over me as a mythic measure against which my era was in every way meager and inconsequential'; quotation on pp. 339-42.

117 Savage, 'The new naturalists', p. 114. See also Savage, 'That's how good it is'; J. Savage, 'Do you know how to pony? The messianic intensity of the sixties', in A. McRobbie, ed., Zoot suits and second-hand dresses: an antbology of fashion and music (Basingstoke, Macmillan, 1989), pp. 121-31. For a more pessimistic view of pop's post-sixties prospects see I. MacDonald, The people's music (London, Pimlico, 2003). 